\title{
The Effect of PDEODE Learning Model on Competency of Electronic and Electronic Basics Lessons Reviewed From The Ability of Formal Reaching Students of Class X TITL A In Raden Rahmat Mojosari Vocational School
}

\author{
Ayu Zulaikha Hidayati1,a*, Ismet Basuki2,b, I. G. P. Asto Buditjahjanto3,c \\ 1 Postgraduate of Technology and Vocational Education, Universitas Negeri Surabaya, Surabaya, Indonesia \\ ${ }^{2}$ Departmen of Electrical Engineering, Universitas Negeri Surabaya, Surabaya, Indonesia \\ ${ }^{3}$ Departmen of Informatics Engineering, Universitas Negeri Surabaya, Surabaya, Indonesia \\ a ayuhidayati16070895019@mhs.unesa.ac.id; b ismetbasuki@unesa.ac.id; c asto@unesa.ac.id \\ ${ }^{*}$ Corresponding Author \\ Whatsapp number: [085746873502]
}

How to Cite : Hidayati, A., Z., Basuki, I., Buditjahjanto, I., G., P., A. (2019). The Effect of PDEODE Learning Model on Competency of Electronic and Electronic Basics Lessons Reviewed From The Ability of Formal Reaching Students of Class X TITL A In Raden Rahmat Mojosari Vocational School. International Journal for Educational and Vocational Studies, 1 (6), 604-608

\section{ARTICLE HISTORY}

Received: 13 June 2019

Revised: 18 July 2019

Accepted: 8 September 2019

\section{KEYWORDS}

PDEODE Learning Models;

Formal Reasoning Skills;

DLE Subjects;

\begin{abstract}
Improving student competence is very dependent on the learning model and students' formal reasoning abilities. This study aims to: (1) analyze differences in competencies between students taught with the PDEODE learning model and students taught using direct learning models in DLE subjects at SMK Raden Rahmat Mojosari, (2) analyze differences in competencies between students who have TKPFT and students who have TKPFR on DLE subjects at SMK Raden Rahmat Mojosari, (3) analyze the interaction between the use of learning models and TKPF on student competencies on DLE subjects at SMK Raden Rahmat Mojosari. This research is a type of experimental research that uses factorial analysis design. Data collection instruments were in the form of passive component social attitude competency observation sheets, passive component knowledge competency test sheets, passive component skills competency performance test sheets and formal reasoning ability test sheets for students. Based on the results of the study, it can be concluded that: (1) there are differences in competencies between students taught using the PDEODE learning model and students taught using direct learning models in DLE subjects at SMK Raden Rahmat Mojosari, (2) there are differences in competencies between students who have TKPFT and students who have TKPFR on DLE subjects at SMK Raden Rahmat Mojosari, (3) there is an interaction between the use of learning models and TKPF on student competencies in DLE subjects at SMK Raden Rahmat Mojosari.
\end{abstract}

This is an open access article under the CC-BY-SA license.

\section{INTRODUCTION}

In relation to the quality of education, what gets the most attention is the creation of a learning climate that is conducive to the implementation of a flexible curriculum in accordance with the potential of the school so that the teacher can implement it systematically and make it easier for students to achieve complete training. So that students know, understand, and understand the material or concept being taught, appropriate teaching methods and models are needed. The most important thing that teachers must realize and think about is how to find solutions for effective, creative, innovative and fun ways of learning, so that the material can be easily understood by students. The traditional view that assumes that knowledge can be transferred in full from the teacher's mind to the student's mind needs to be shifted towards a constructivism view which assumes that knowledge is built in students through experience. Understanding develops stronger when tested with new experiences (Trianto, 2007: 108-109).

In the Electrical Power Engineering Expertise Competency (TITL) at SMK Raden Rahmat Mojosari there are competencies that must be mastered by students, one of them is DLE competency. This competency is one of the subjects for class X students. Mastery of DLE material 
is needed because the material is the basic material that will be very useful for further learning material.

Based on the results of observations at SMK Raden Rahmat Mojosari in odd and even semester of the $2017 / 2018$ academic year, the competence was less than optimal. Student competencies obtained at the time of observation are that most students get grades below the KKM with a maximum completeness criteria (KKM) of 70 , so it needs to be remedial to get good grades. From observations during the learning process, some students do not pay attention to the teacher's explanation, students also do not read textbooks and do not do worksheets if not asked or instructed by the teacher and when teachers give homework to students, they do it at school.

Such conditions are caused by the use of direct learning models in teaching and learning activities that have some weaknesses, namely all learning processes are centered on the teacher, students are dependent on the teacher, students do not do pactics before the teacher demonstrates the material taught in detail by the teacher, students will not read books lesson or do worksheets before the teacher explains the material first and give orders. This causes the lack of independence, creativity and responsibility of students while learning so as to obtain a less good competency score In addition, students are less able to think scientifically and less able to reason formally because they are not trained to think independently, cannot solve their own problems and cannot find answers to their own problems.

To achieve these objectives teachers are expected to choose good teaching methods and choose the appropriate method. It would be better if the use of teaching methods can be varied according to the learning material, because if only certain methods will be used it will not provide opportunities for students to develop creativity and thinking power, and can make students feel bored. To convey the material is not just trying to transfer the teacher's knowledge to students as a whole, but trying to stimulate and provide opportunities for students to express and find solutions by finding their own. One learning model that is able to overcome the above problems is to use the PDEODE learning model.

According to Costu (2008), the PDEODE learning model is able to train students to develop scientific concepts because students can think independently, discuss in groups, conduct and observe experiments directly, compare students' initial concepts with observations and then students discover new concepts that are more scientific. The PDEODE model was initially suggested by Savander Ranne \& Kolari (2003) and was first used by Kolari Et al., (2005) in the world of education. Most important in learning with this model are supporting discussions and various views. This model is very appropriate for use in learning because students themselves must find and transform complex information, check new information compared to old rules and improve those rules if they no longer fit the constructivism view.

Formal reasoning ability is a part of basic abilities such as talents possessed by each individual that allows them to achieve a specific skill, knowledge and skill. Reasoning ability is very influential on learning outcomes that are generally not real that need formal reasoning to understand it. A student who is able to think logically in learning and understanding concepts, where the student is able to learn the structure of science itself, then the student will not be left behind in his learning. Thus it means that, formal reasoning ability possessed by students plays an important role in mastering concepts optimally.

\section{METHODS}

The type of research used is experimental research. The purpose of this study was to determine the differences in the competencies of students who use the PDEODE learning model with the competencies of students who use a direct learning model on DLE subjects in terms of the student KPF. The independent variable in this study is the learning model, where one group of students is taught using the PDEODE learning model and one group is taught using the direct learning model. The independent variable will be manipulated and measured its effect on the dependent variables, namely student competence by taking into account the moderator variables that affect treatment. The moderator variable in this study was student KPF where student KPF was measured and classified to determine TKPFT and TKPFR.

This research uses factorial design. Sugiyono states factorial design is a modification of quasi experimental design, that is by observing the presence of moderator variables that influence treatment (independent variables) on competence (dependent variable) (2016: 115). Factorial design research designs are described as in Figure 1 below.

\subsection{Factorial Design $2 \times 2$}

\begin{tabular}{|llll|}
\hline $\mathbf{E}$ & $\mathbf{O}_{1}$ & $\mathbf{X}_{1} \mathbf{Y}_{1}$ & $\mathbf{O}_{3}$ \\
& & $\mathbf{X}_{1} \mathbf{Y}_{2}$ & $\mathbf{O}_{4}$ \\
\hline $\mathbf{K}$ & $\mathbf{O}_{2}$ & $\mathrm{X}_{2} \mathbf{Y}_{1}$ & $\mathbf{O}_{5}$ \\
& & $\mathbf{X}_{2} \mathbf{Y}_{2}$ & $\mathbf{O}_{6}$ \\
\hline
\end{tabular}

Figure 1. Factorial Design Research Source: Sugiyono (2015: 115)

The description of the above notation is as follows.

\begin{tabular}{|c|c|}
\hline $\mathrm{E}$ & $=$ Experimentation Class \\
\hline $\mathrm{K}$ & $=$ Control class \\
\hline $\mathrm{O} 1,2$ & $=$ Pre-test \\
\hline $\mathrm{O} 3,4,5,6$ & $=$ Post-test \\
\hline $\mathrm{X} 1$ & $\begin{aligned}= & \text { Treatment in the experimental class } \\
& \text { (using the PDEODE learning model) }\end{aligned}$ \\
\hline $\mathrm{X} 2$ & $\begin{array}{l}=\text { Treatment in the control class (using the } \\
\text { direct learning model) }\end{array}$ \\
\hline Y1 & $=\mathrm{TKPFT}$ \\
\hline $\mathrm{Y} 2$ & $=\mathrm{TKPFR}$ \\
\hline
\end{tabular}




\subsection{Statistical Data Analysis}

Data Analysis of Covariance (ANCOVA) was used to analyze significant in different level of treatment with probability $5 \%$.

\section{RESULTS AND DISCUSSIONS}

3.1 There are differences in competencies between students taught using the PDEODE learning model and students taught using the direct learning model.

In this study, the competencies of students taught using the PDEODE learning model were higher than the competencies of students taught using the direct learning model. These results are based on the findings that: (1) the average score of social attitude competence in the experimental class was 89.74 and the control class was 67.37 ; (2) the average score of students' knowledge competence in the experimental class was 87.09 and the control class was 60.57 ; and (3) the average score of students' competency skills in the experimental class was 90.02 and the control class was 66.94.

The competency results taught by the PDEODE model are in line with the constructivist theory proposed by Piaget as follows: (1) focusing on thinking or mental processes and not merely on the results, (2) prioritizing the role of students in their own initiative and active involvement in learning activities and (3) understand the existence of individual differences in terms of development progress. All students grow through the same sequence of developments, but take place at different speeds. Even though it is difficult in the process of learning activities, the results they obtain will last long term, as shown in the competency results of social attitudes, knowledge and skills.

Where as by using the direct learning model the competency score will be lower compared to PDEODE. This is in line with the theory put forward by Arends that the direct learning model is rather easy and can be mastered in a relatively short time. This means that although the learning process is easier and directly understood by students at the time, but in the long run it will be difficult to remember again the understanding of the material because students in the direct learning model are accustomed to getting modeling from the teacher and cannot solve and cannot find own problems in learning.

Overall, the results of this study are in accordance with the results of previous relevant studies. The PDEODE learning model has a positive impact on student competencies in the Department of Electrical Power Engineering. The PDEODE learning model is able to train students to develop scientific concepts because students can think independently, discuss in groups, conduct and observe experiments directly, compare students' initial concepts with observations and then students discover new, more scientific concepts.

Most important in learning with this model are supporting discussions and various views. This model is very appropriate for use in learning because students themselves must find and transform complex information, check new information compared to old rules and improve those rules if they no longer fit the constructivism view.

This model is very appropriate to be used in DLE subjects in Vocational Schools because it dominates the role of students in learning compared to the teacher, the teacher is only as a facilitator. Students who find their own answers to problems given by the teacher while the teacher only directs so that the knowledge obtained by students last longer in the brain.

Based on the findings in the field when learning takes place, students who are taught with the PDEODE learning model are more enthusiastic, active and eager to follow the process of learning activities. The more he is given a problem, the more he is challenged to find out the answer to that problem. Then, when they have found it, they will associate their findings with existing theories.

Unlike students who are taught with a direct learning model, they are not so enthusiastic in participating in learning. Students look less enthusiastic and tend to be passive. When the teacher explains or demonstrates the skills, many students do not pay attention to the teacher's explanation. And if told to repeat the skills taught, they will be difficult to do because they forget and pay less attention. Students taught with this model need more modeling from the teacher to be able to re-understand the material being taught.

From the analysis of the results of the study it was found that in the three competencies measured, both in social attitude competencies, knowledge competencies and skills competencies all showed that students who were taught using the PDEODE learning model were superior in competence compared to control class students who were taught using direct learning models.

\subsection{There are competency differences between students who have a high level of formal reasoning ability and students who have a low level of formal reasoning ability.}

According to Nur (1991) To achieve better competence, students must have a high level of formal reasoning ability. A high level of formal reasoning ability is indicated by indicators (a) has proportional reasoning ability, (b) has variable controlling ability, (c) has probabilistic reasoning ability, (d) has correlational reasoning ability and (e) has combinatorial reasoning ability.

Conversely students who have a low level of formal reasoning ability will tend to be passive and slow individuals in exploring information, characterized by indicators (a) lacking proportional reasoning ability, (b) lacking variable controlling ability, (c) lacking probabilistic reasoning abilities, (d) lacks correlational reasoning ability and (e) lacks combinatorial reasoning ability.

Overall, the results of this study are in accordance with the results of previous relevant studies. In this study 
it was found that students with TKPFT had good motivation in learning. However, not always students with TKPFT are released in learning just like that. Students with TKPFT still need support from the teacher as a facilitator in the classroom. In practice, if teachers do not play an active role in supporting students in classroom practice, students with TKPFT experience a decrease in motivation in learning.

Thus, TKPF gives effect to several aspects of student competencies including social attitude competencies, knowledge, and skills. The results of this study are in line with the theory discussed above. A student who has TKPFT will be able to achieve high competence, conversely students who have TKPFR will be able to achieve low competence. The higher TKPF students, the higher the competency of students.

\subsection{There is an interaction between the use of learning models and the level of formal reasoning ability on student competencies.}

The results showed an interaction between the use of learning models and TKPF on student competencies in DLE subjects. This is indicated by the results of the analysis of student competency scoring data. This shows that: (1) there is an interaction between the learning model and the ability of formal reasoning to the competence of students' social attitudes; (2) there is an interaction between the learning model and the formal learning ability of students' knowledge competencies; and (3) there is an interaction between the use of learning models and the ability to formally address students' competency skills.

Competencies of students who have TKPFT have higher scores in all competencies, both social attitude competencies, knowledge competencies and skills competencies. In contrast, the competencies of students who have TKPFR have lower scores in all areas of competence, both social attitude competencies, knowledge, and skills. Thus, it can be concluded that the use of learning models in the classroom supported by TKPF students is able to have a positive impact on the results of their competence.

The enthusiasm of students with TKPFT was also better in the experimental class, this was evidenced from the results of scoring the competence of students' social attitudes. The activities in the experimental class such as asking questions and discussing are more done than if they were in the control class who were learning by using a direct learning model that lacked discussion.

The activities of students with TKPFR are in contrast when compared to students who have TKPFT, students with TKPFR tend to choose simple problems to solve. TKPR students are less active in discussion and problem solving analysis activities. This is what underlies that the competency score of social attitudes, knowledge, and skills of TKPFR students is smaller in the experimental class. Conversely, in the control class learning to use the direct learning model TKPFR student competencies are better than TKPFT students, this is because students with TKPFT are not enthusiastic when in the control class who only learn to use the direct learning model so that the TKPFR student competencies are higher compared to students TKPFT.

Students with TKPFT, suitable to learn by using the PDEODE learning model, because students with TKPFT have a high curiosity and curiosity and a sense of reason, so they are challenged to learn DLE subjects better. Conversely, students with TKPFR are suitable to learn by using direct learning models because students with low TKPF have lower interest in something new or it can be said that these students have a curiosity and low reasoning power.

The use of appropriate learning models can generate motivation and be able to train students' formal reasoning abilities to achieve maximum learning goals. As it is known that the formal reasoning ability of vocational students can be trained with learning models that are problem solving and problem analysis, one of which is the PDEODE learning model. Thus, it can be concluded that the ability of formal vocational schooling students can be improved through the learning model that is applied by teachers in the classroom.

In addition to the above conclusions, the new findings obtained in this study are that there is student enthusiasm (motivation) that can arouse the students' formal reasoning abilities in learning if using an interesting learning model, namely the PDEODE learning model compared to the learning model that is centered on teacher only or direct learning model.

\section{CONCLUSION}

a. There is a difference in competence between students taught using the PDEODE learning model and students taught using the direct learning model in DLE subjects at SMK Raden Rahmat Mojosari.

b. There is a difference in competence between students who have TKPFT and students who have TKPFR on DLE subjects at SMK Raden Rahmat Mojosari.

c. There is an interaction between the use of learning models and TKPF on student competencies in DLE subjects at SMK Raden Rahmat Mojosari.

\section{REFERENCES}

Abdurrahman, M., (1999). Pendidikan bagi anak berkesulitan belajar. Jakarta: Rineka Cipta.

Achmad, S. (2017). Analyzing educational university students' conceptions through smartphone-based pdeode*e tasks on magnetic field in several mediums. Mathematics, Science, and Computer Science Education (MSCEIS 2016). Advance online publication. Doi: 10.1063/1. 4983963.

Arikunto, S. (2001). Prosedur penelitian. Jakarta: Rineka Cipta. 
Arikunto, S. (2008). Evaluasi program pendidikan. Jakarta: Bumi Aksara.

Bayram, C. (2008). Learning science through the pdeode teaching strategy: helping student make sence of everyday situations. Eurasia Journal of Mathematics, Science \& Technology Education, 14(1), 39-43.

Bayram, C., Alipasa, A., \& Mansoor, N. (2011). Investigating the effectiveness of a poe-based teaching activity on students, understanding of condensation. Springer Science and Business Media. Advance Online Publication. Doi: 10.1007/s11251-011-9169-2.

Blocher, Richard. (2004). Dasar elektronika. Yogyakarta: Andi.

Carina, S. R., \& Samuli, K. (2003). Promoting the conceptual understanding of engineering students through visualisation. Global J. of Engng. Educ.,7(2), 184-194.

Dimyati dan Mudjiono. (1999). Belajar dan pembelajaran. Jakarta: Rineka Cipta.

Dimyati dan Mudjiono. (2006). Belajar dan pembelajaran. Jakarta: Rineka Cipta.

Kehinde, A. A., Jumoke, B. B., \& Olajumoke, S. (2017). Effectiveness of learning cycle models on nigerian senior secondary students' anxiety towards chemistry. British Journal of Education, Society \& Behavioral Science, 21(1), 1-13.

Moeslim, S. (2013). Kisi-kisi lembar pengamatan hasil belajar. Surabaya: Unipres Unesa.

Nur, (2000). Pengajaran langsung. Surabaya: University Press.

Raden, R. W., Siswoyo, Fauzi, B. (2015). Pengaruh model pembelajaran pdeode terhadap hasil belajar kognitif fisika siswa SMA. Seminar Nasional Fisika, 4(3), 199-210.

Riduwan. (2006). Dasar-dasar statistika. Bandung: Alfabeta.

Rusyan, Tabrani., Kusdinar, Atang, Arifin, Zainal. (1989). Pendekatan dalam proses belajar mengajar. Bandung: Remaja Karya.

Sudjana, Nana. (2001). Penilaian hasil proses belajar mengajar. Bandung: Remaja Rosda Karya.

Sudjana. (2005). Metoda statistika. Bandung: Tarsito.

Sugiyono, (2009). Metode penelitian kuantitatif kualitatif dan R\&D. Bandung: Alfabeta.

Tabitha, S. H. W., Mohamad, A., Siti, Z., \& Mimien, H. (2017). Students' critical thinking improvement through pdeode and stad combination in the nutrition and health lecture. International Journal of Evaluation and Research in Education (IJRE), 6 (2), 110-117.

Tismi, D., \& Aloysius, D., C. (2016). The effect of pdeode learning strategy in the different academic abilities on students' critical thinking skills in senior high school. European Journal of Education Studies, 2(5), 11-21.
Tismi, D., Herawati, S., \& Aloysius, D. C. (2016) Pengaruh strategi pembelajaran pdeode pada kemampuan akademik berbeda terhadap hasil belajar siswa di kota Makassar. Seminar Nasional IIFKIP dengan Studi Lingkungan dan Kependudukan. 12 (3), 15-26.

Tabitha, S. H. W., Mohamad, A., Siti, Z., \& Mimien, H. (2016). The effect of pdeode strategy on the concept and retention mastery in nutrition and health course on students with different ability. ICTTE FKIP UNS, 1(1), 52-65.

Trianto. (2007). Model pembelajaran terpadu dalam teori dan praktik. Jakarta: Prestasi Pustaka Publisher.

Uno, Hamzah. (2006). Perencanaan pembelajaran. Jakarta: Bumi Aksara. 